\title{
PHASE TRANSITIONS IN CONVECTION
}

\author{
Ivan V. Gushchin, (D)Volodymyr M. Kuklin*, Deugen V. Poklonskiy \\ V.N. Karazin Kharkiv National University, Kharkiv, Ukraine \\ Svobody Sq. 4, Kharkiv, Ukraine, 61022 \\ *E-mail:kuklinvm1@gmail.com
}

Received July 30, 2019; revised October 4, 2019; accepted October 10, 2019

The paper presents the results of the study of the models of convective instability near its threshold of thin layers of liquid and gas bounded by poorly conducting walls. These models single out one spatial scale of interaction, leaving the possibility for the evolution of the system to choose the symmetry character. This is due to the fact that the conditions for the realization of the modes of convective instability near the threshold are chosen. All spatial perturbations of the same spatial scale, but of different orientations, interact with each other. It turned out that the presence of minima of the interaction potential of the Proctor-Sivashinsky equation modes, the absolute value of the wave number vectors of which is unchanged, determines the choice of symmetry and, accordingly, the characteristics of the spatial structure. In the case of a more realistic model of convection described by the Proctor-Sivashinsky equation, it was possible to observe both the first-order phase transition and the second-order phase transition and detect the form of the state function, which is responsible for the topology of the resulting convective structures: metastable rolls and stable square cells. In this paper, it is shown that the nature of the structural-phase transition in a liquid when taking into account the dependence of viscosity on temperature in the Proctor-Sivashinsky model is similar to the case of the absence of such a dependence. The transition time turns out to be the same, despite the fact that a different structure is formed - hexagonal convective cells. As in the SwiftHohenberg model, a hard mode for the formation of hexagonal cells in a gas medium is possible only for a sufficiently noticeable dependence of its viscosity on temperature. The phase transition times are inversely proportional to the difference in the values of this function for two consecutive states. A similar description of phase transitions did not use phenomenological approaches and various speculative considerations, which allows for a closer look at the nature of transients.

KEYWORDS: first-order phase transition, the second-order phase transition, state function, convective structures, Swift-Hohenberg, Proctor-Sivashinsky models.

Below, we discuss the possibility of phase transitions in a thin layer of liquid or gas, between walls with poorly conducting heat. The layer is limited only from below and above, in other directions there are no borders.

We first consider the Proctor-Sivashinsky equation with allowance for the temperature dependence of viscosity $[1,2]$ in the case of the proximity of the Rayleigh number to the critical value of the occurrence of convection $R a_{c}$, that is, $R a=R a_{c}(1+\varepsilon)$

$$
\frac{\partial \phi}{\partial T}+\nabla^{4} \phi+\nabla\left[\left(2-\gamma \phi-(\nabla \phi)^{2}\right) \nabla \phi\right]+a \phi=0
$$

where $\varepsilon<<1, \nabla \phi=\vec{i} \cdot \frac{\partial \phi}{\partial \zeta}+\vec{j} \cdot \frac{\partial \phi}{\partial \vartheta}$ is a two-dimensional operator, and, $\vec{i}, \vec{j}$ are single unit orthogonal to each other unit vectors in the $(\zeta, \vartheta)$ plane of the media separation, and we will assume $k_{0} \approx 1$, since we restrict ourselves to the case of a weak excess over the threshold of convective instability. Indeed, for any deviation of the wavenumber from unity, the perturbation amplitude rapidly decreases. Here $\phi$ is the relative temperature at the upper boundary of the layer. An increase in this value indicates an increase in the thermal conductivity of the layer as a whole.

Table 1.

Transition from used variables to real physical quantities

\begin{tabular}{|c|c|c|}
\hline \multicolumn{2}{|c|}{ Physical Value } & Representation \\
\hline Temperature & $T(x \sqrt{\varepsilon}, y)$ & $T_{d}+\left(T_{d}-T_{u}\right)(-y+F(x \sqrt{\varepsilon}, y)$ \\
\hline Horizontal speec & $\psi_{y}$ & $60 \sqrt{\varepsilon} \cdot F_{x \sqrt{\varepsilon}} \cdot\left(2 y^{3}-3 y^{2}+y\right)$ \\
\hline Vertical speed & $-\psi_{x}$ & $-30 \varepsilon \cdot\left(F_{x \sqrt{\varepsilon}}\right)_{x \sqrt{\varepsilon}} \cdot\left(y^{4}-2 y^{3}+y^{2}\right)$ \\
\hline
\end{tabular}

where $\xi=x \sqrt{\varepsilon}, \eta=y, F=\phi \cdot \sqrt{17 / 660}$.

Equation (1) contains vector quadratic nonlinearity (that is, dependent on the orientation of perturbations and derived quantities), and the cubic nonlinearity, which takes into account the influence of the temperature field at the upper boundary of the layer, responsible for the change in the topology of spatial structures of convection.

To describe such convection under the same conditions, the simplified Swift-Hohenberg equation is often used [3] (C) Ivan V. Gushchin, Volodymyr M. Kuklin, Eugen V. Poklonskiy, 2019 


$$
\frac{\partial \phi}{\partial T}=e \phi-\left(1+\nabla^{2}\right)^{2} \phi-2 \gamma \phi^{2}+3 \phi^{3}
$$

where the vector character of the nonlinear terms is replaced by the scalar one. Here $e=(1-a)$, where such dependences are chosen $\beta=a \cdot \sqrt{231 / 68}$, and the dimensionless heat transfer coefficient between the fluid and the boundary, here equals the number of Biot and is equal to $b=\varepsilon^{2} \cdot \beta$.

The growth of disturbance amplitudes in case of instability $\phi \propto \exp \{\operatorname{Im} \omega \cdot T\}$ occurs with an increment $\operatorname{Im} \omega \approx e-\left(k^{2}-1\right)^{2}$. For $\gamma>0$ gas flow (this corresponds to gas convection) it goes back to the center of the cell, with $\gamma<0$ (which corresponds to the movement of the liquid) - vice versa.

The Swift-Hohenberg equation, as noted in the review [4], describes, after the formation of an amorphous state of disorderly convection, a system of distinct hexahedral cells as a result of a soft (for liquid) and hard (for gas) instability regime, observed in particular in [5]. Moreover, the nature of the instability demonstrates all the features of the firstorder phase transition - the formation of a clear spatial structure of convection from an amorphous state.

The purpose of the work is the analysis of the soft and hard regimes of structural-phase transitions in the ProctorSivashinsky model in the conditions of temperature dependence of viscosity.

\section{DESCRIPTION OF PHASE TRANSITIONS IN THE MODEL OF THE PROCTOR-SIVASHINSKY IN THE ABSENCE OF TEMPERATURE DEPENDENCE OF VISCOSITY}

In contrast to the traditionally used Swift-Hohenberg equations, we use the 3D Proctor-Sivashinsky equation that meets the real conditions. This task is obviously three-dimensional in space and non-stationary, which at first glance creates significant problems. However, the Proctor-Sivashinsky model makes it possible to reduce the dimension of the description and focus on topological aspects, that is, appearance, size and development time of spatial structures.

In the case of a more realistic model of convection, described by the Proctor-Sivashinsky equation (1), both the first-order phase transition and the second-order phase transition can be observed, and the state function, which is responsible for the topology of the resulting convective structure, was detected [6].

The equation that determines the dynamics of the temperature field of this process in the horizontal plane $(x, y)$ is:

$$
\frac{\partial \Phi}{\partial T}=\varepsilon^{2} \Phi-\left(1-\nabla^{2}\right)^{2} \Phi+\frac{1}{3} \nabla\left(\nabla \Phi|\Phi|^{2}\right)+\varepsilon^{2} f,
$$

where $\Phi=\theta / \sqrt{3}, \varepsilon^{2}=e, f$ - is a random function describing external noise, $\theta$ - the temperature deviation from the equilibrium one (varying according to a linear law), and the magnitude $\varepsilon$ determining the excess of the convection development threshold, we suppose, as before, to be quite small $(0<\varepsilon<1)$. We present the solution in the form of $\Phi=\varepsilon \sum_{j} A_{j} \exp \left(i \vec{k}_{j} \vec{r}\right)$ with $\left|\vec{k}_{j}\right|=1$.

For replacements $T \cdot \varepsilon^{2}=t$, for slow amplitudes in the absence of noise, we obtain a mathematical expression for the Proctor-Sivashinsky model for describing convection.

$$
\frac{\partial A_{j}}{\partial t}=A_{j}-\gamma A_{j+j_{0}} A_{j+2 j_{0}}-\sum_{i=1}^{N} V_{i j}\left|A_{i}\right|^{2} A_{j},
$$

where the interaction coefficients are defined by the relations $V_{j j}=1$ and $V_{i j}=(2 / 3)\left(1+2\left(\vec{k}_{i} \vec{k}_{j}\right)^{2}\right)=(2 / 3)\left(1+2 \cos ^{2} \vartheta_{i j}\right), \vartheta-$ the angle between the vectors $\vec{k}_{i}$ and $\vec{k}_{j}$ with the initial values of the amplitudes of the spectrum $\left.A_{j}\right|_{t=0}=A_{j_{0}}, \vartheta_{j_{0}}=2 \pi / 3$.

The analysis of the Proctor-Sivashinsky model in the absence of the dependence of viscosity on temperature $(\gamma=0)$ was studied in detail by authors of this work earlier [7]. It was shown that after the first-order phase transition, a quasistable system of convective rolls (the form of which is shown in Fig. 1a) is formed from amorphous random convection of a state. Later, as a result of rolls modulation within the framework of a second-order phase transition, form a stable field of square convective cells (the form of which is shown in Fig. 1b).

The first-order structural-phase transition, noted earlier in [4], corresponds to the transition from an amorphous state of convection to a state that has the form of a pronounced spatial structure. It should be emphasized that such a spatial clarity of the structure is observed only in conditions of proximity to the instability threshold. If, as a result of instability, the topology of the structure changes, we can speak of a second-order structural-phase transition.

In this case, the phase transition times are inversely proportional to the difference in the values of the state function $\sum_{i} A_{i}{ }^{2}$.

$$
\tau_{n} \sim\left\{\left(\sum_{i} A_{i}^{2}\right)_{n}^{(+)}-\left(\sum_{i} A_{i}^{2}\right)_{n}^{(-)}\right\}^{-1}=\Delta I_{n}^{-1}
$$


It was the fulfillment of the last relation that allowed us to consider the value as a state function, since each spatial structure of convection uniquely corresponded to its value of this function, besides, the phase transition time was also related to the changes of the magnitudes of this function (these changes can be seen in Fig. 2). The fragments of the spatial structure of the temperature field distribution on the surface of layer are presented in Fig. 3.
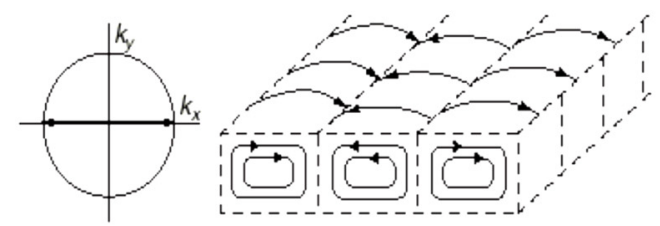

a

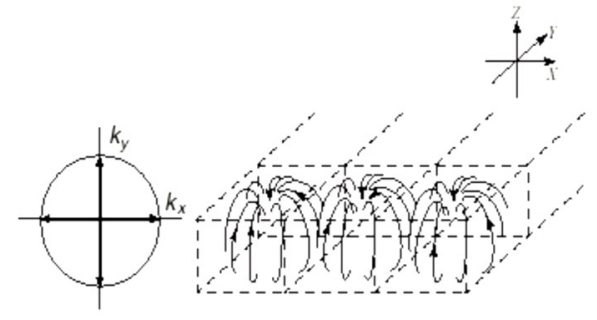

b

Fig. 1. Convective structures: rolls (a) and square cells (b)

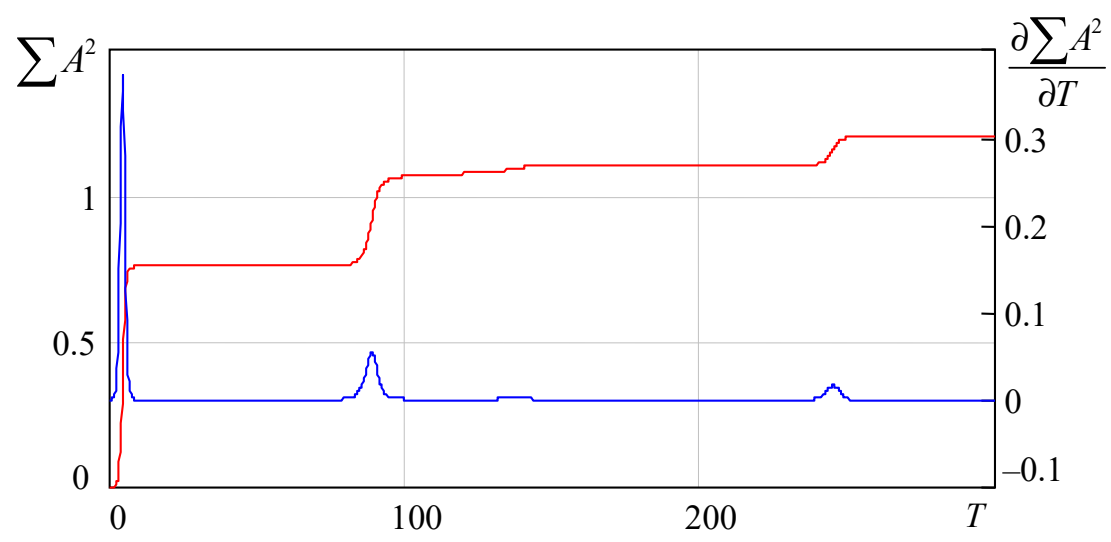

Fig. 2. Behavior of the quantity $\sum A^{2}$ (upper curve) and its derivative $\partial \sum A^{2} / \partial T$ of time $T$
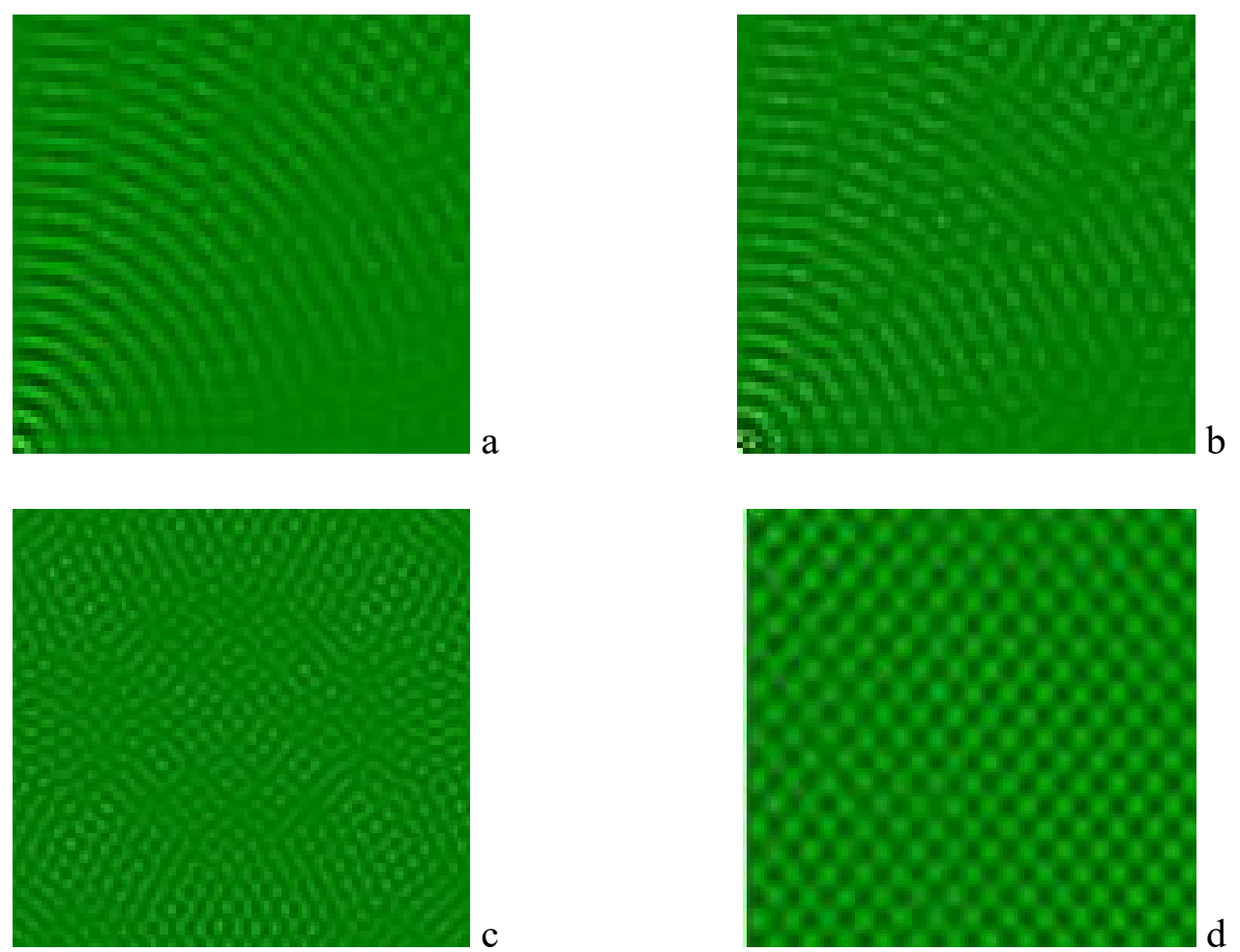

Fig. 3. The appearance of fragments of the spatial structure of the temperature field distribution on the surface of layer a) - after the structural phase transition of the first kind with the formation of convective rolls, b) - with the transverse modulation of the rolls, c) - with the formation of a metastable spatial structure, after the destruction of the system of rolls, d) - with the formation of a stable convective structure - square convective cells. 


\section{PHASE TRANSITIONS IN THE PROJECT-SIVASHINSKY MODEL UNDER THE CONDITIONS OF VISCOSITY DEPENDENCE ON TEMPERATURE}

Soft mode of excitation of a six-sided convective structure. Taking into account the temperature dependence of viscosity demonstrates the ability to implement soft (when $\gamma<0$ ) and hard (that is, setting the initial perturbation already in the form of the desired structure $20 \%$ higher than the average values of the amorphous state upon $\gamma>0$ ) excitation of six-sided convective cells, the state function of which is almost equal to the state function of the rolls system. The time of the first-order structural-phase transition from the amorphous state is almost the same. When negative $\gamma<0$ is observed, as in the Swift-Hohenberg model, the mode of soft excitation of six-sided convective cells (Fig. 4).

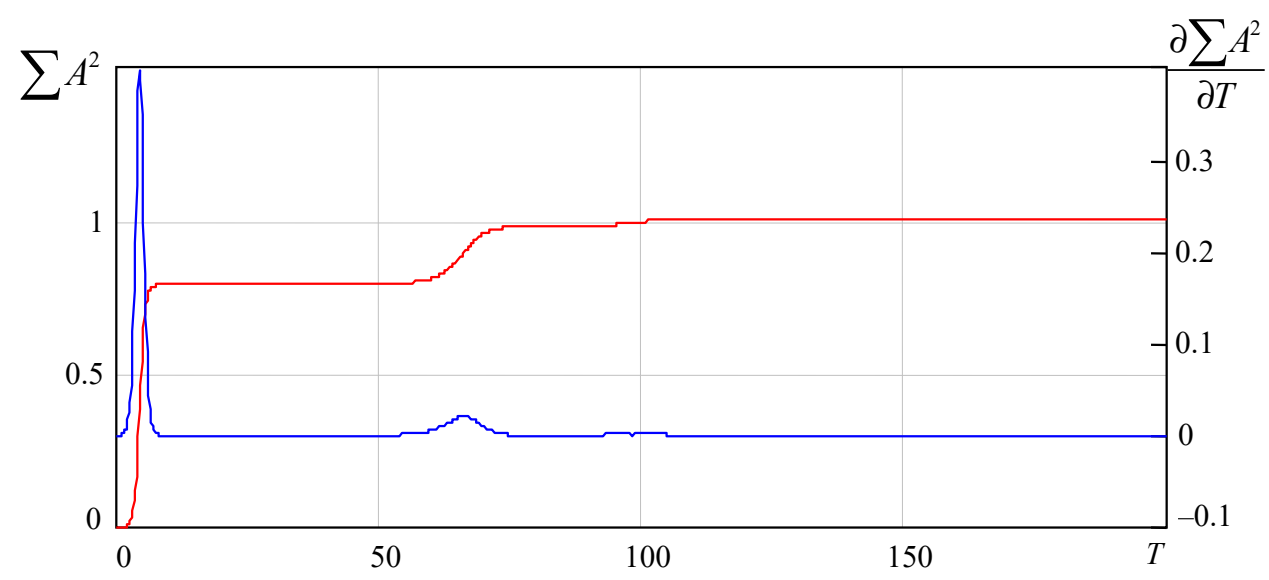

Fig.4. Behavior of the value $\sum A^{2}$ (upper curve) and its derivative of time $T, \partial \sum A^{2} / \partial T$ in soft mode excitement at $\gamma=-0.25$

The time interval of the first-order phase transition is equal $\tau_{2}$, but despite the fact that the values of the state function are equal to unity, which in the former case of the absence of the temperature viscosity dependence $(\gamma=0)$, corresponded to a system of convective rolls. But in that case the system of six-sided cells is formed, as can be seen in Fig. 5, which depicts the dynamics of the instability spectrum.

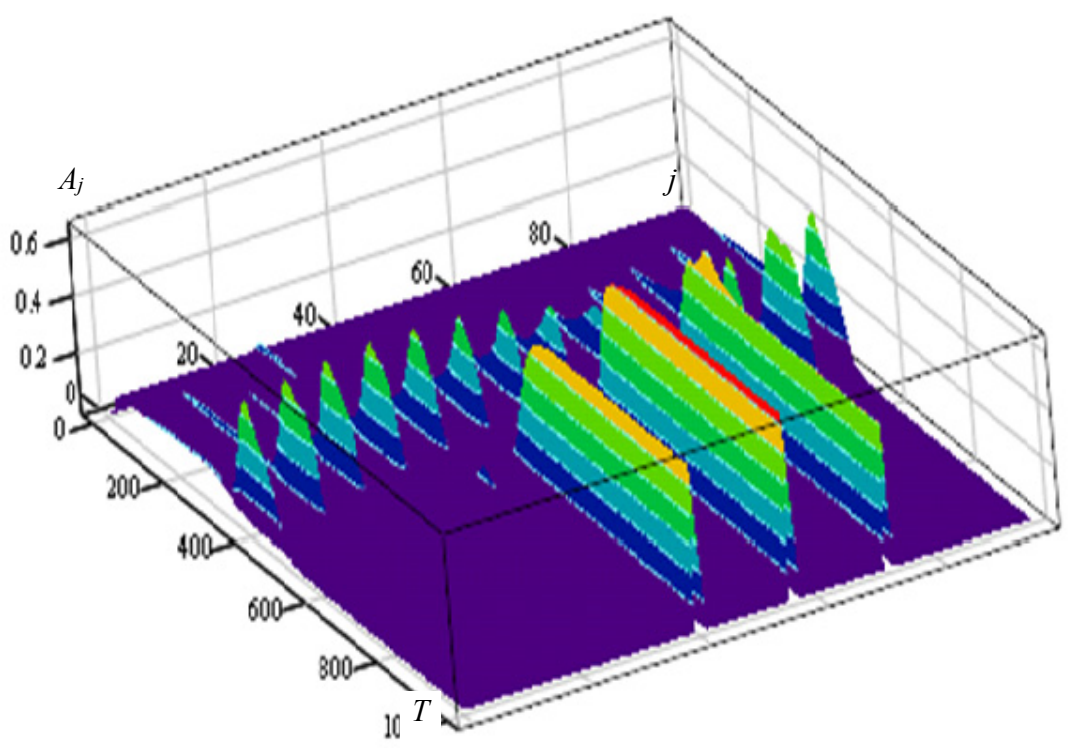

Fig. 5. Dynamics of the instability spectrum with soft imbalance mode $(\gamma=-0.25)$

Hard mode convective hexagon structure. In the case of $\gamma>0$ mode only hard excitation possible, that is, the initial conditions must be specified in the form of hexagonal convective perturbations, clearly expressed against the background of fluctuations. Under these conditions, all characteristics of the process are similar to the case of mild excitation at the same values $|\gamma|$. Otherwise, the dynamics of the process even in the case of non-zero $\gamma>0$ is similar to the case of the absence of dependence of viscosity on temperature, discussed above.

To implement a hard mode against the background of an amorphous state, a structure was formed whose amplitude was $20 \%$ higher than the average value of the amplitudes of the modes (Fig. 6). 


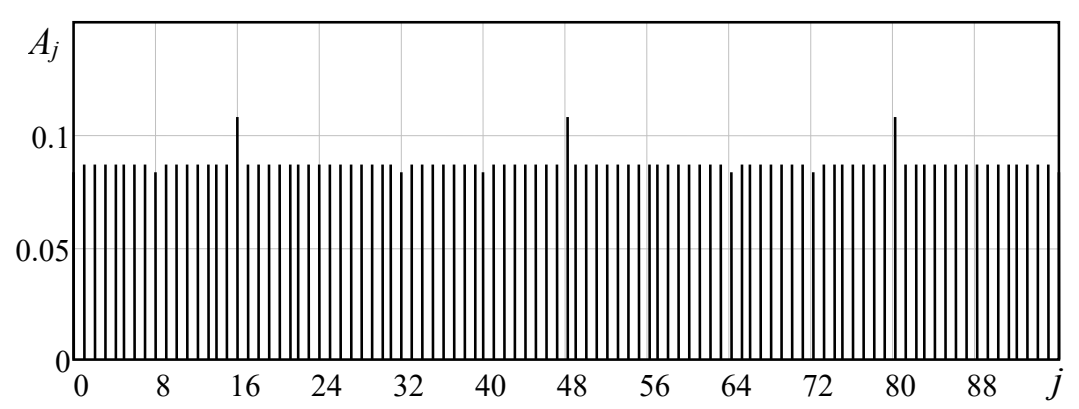

Fig. 6. The initial state of the spectrum of modes on the background of the amorphous state of the system before the phase transition in a gaseous medium $(\gamma>0)$

The behavior of the state function $\sum A^{2}$ and the derivative of time $\partial \sum A^{2} / \partial T$ is presented in Fig. 7 and Fig. 8 respectively.

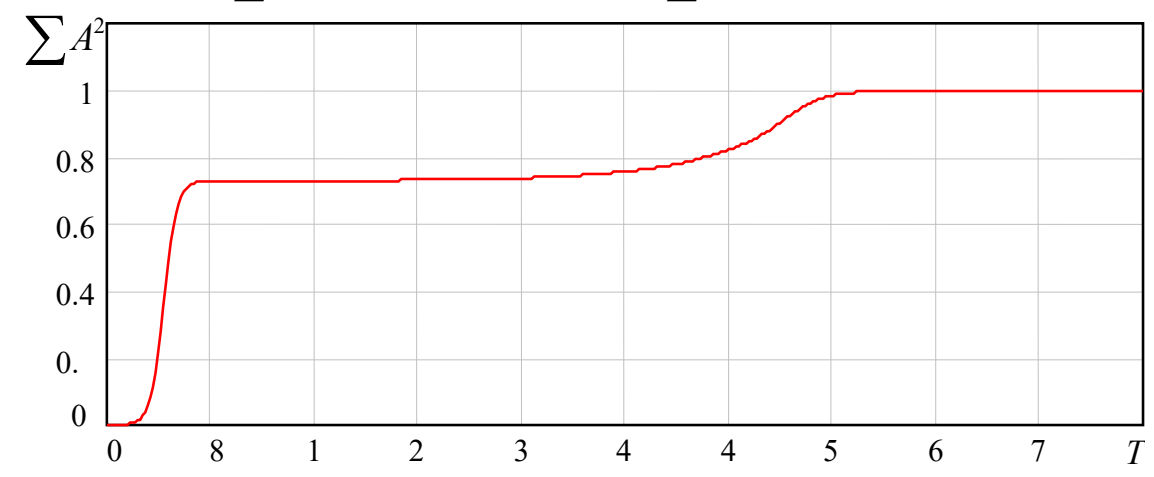

Fig. 7. Behavior of the value of time $T$ in hard excitation mode $\gamma=0.2$

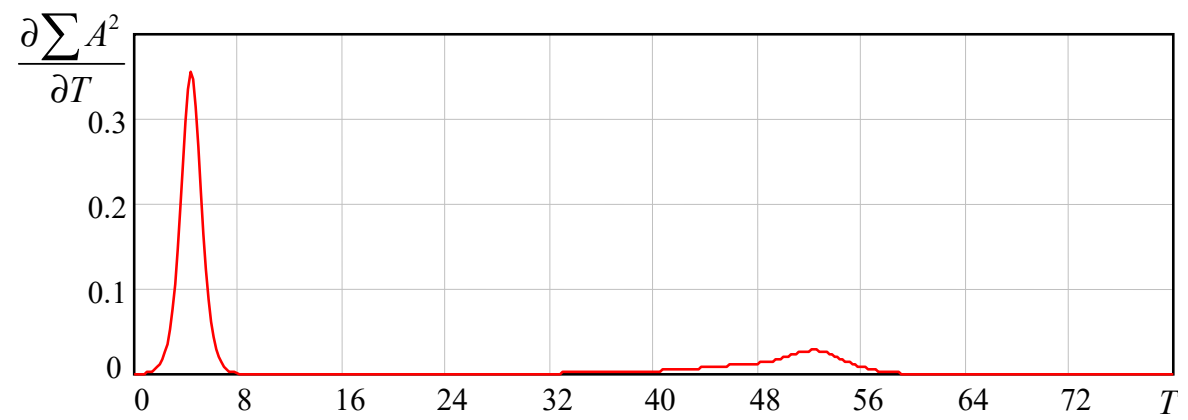

Fig. 8. Behavior of the value of time $T$ in hard excitation mode $\gamma=0.2$

The dynamics of spectrum formation are shown in Fig. 9. The change $1<j<100$ corresponds to a change in angle $0<\vartheta<2 \pi$. The appearance in the spectrum of three modes shifted by $2 \pi / 3$ corresponds to the formation of hexagonal cells.

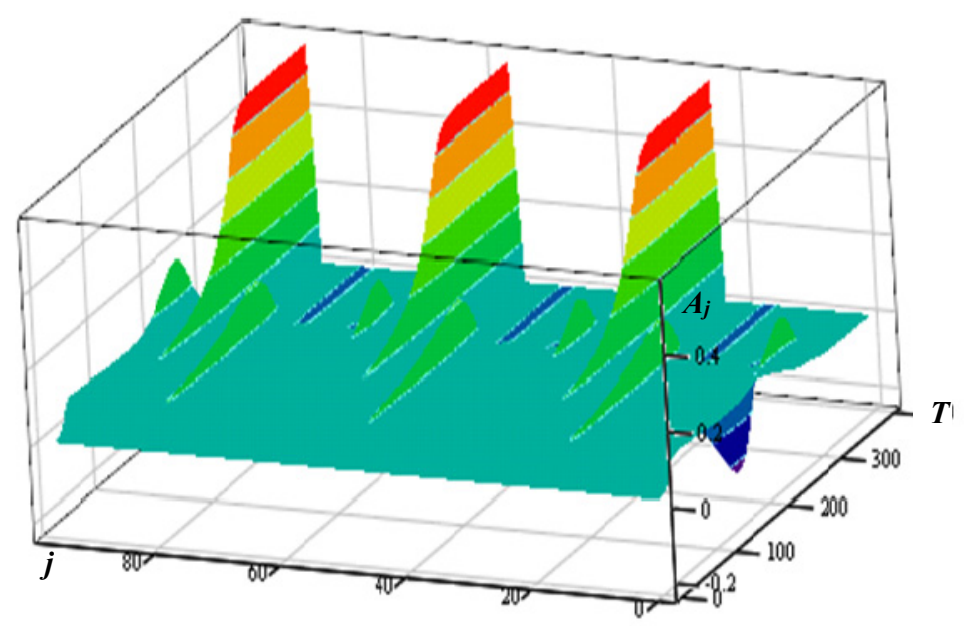

Fig. 9. Instability spectrum dynamics with hard imbalance mode $(\gamma=0.2)$ 


\section{CONCLUSIONS}

The peculiarity of the models describing convective instability of thin layers of liquid and gas, bounded by poorly conducting walls of Swift-Hohenberg and Proctor-Sivashinsky, is that they single out one spatial scale of interaction, leaving the possibility for the evolution of the system to choose the symmetry character. This is due to the fact that the conditions for the realization of the modes of convective instability near the threshold of convective instability are chosen. All spatial perturbations of the same spatial scale, but of different orientations, interact with each other. It turned out that the presence of minima of the interaction potential of the Proctor-Sivashinsky equation modes, the absolute value of the wave number vectors of which is unchanged, determines the choice of symmetry and, accordingly, the characteristics of the spatial structure. It was in the case of a more realistic model of convection, described by the Proctor-Sivashinsky equation (1), that we were able to observe both the first-order phase transition and the second-order phase transition and detect the form of the state function that is responsible for the topology of the resulting convective structures.

It should be noted that such a description of phase transitions did not use phenomenological approaches and various speculative considerations, which makes it possible to more closely examine the nature of the transient processes, which arouses the greatest interest of researchers. It is necessary to pay attention that presented on Fig. $3 \mathrm{c}$. a metastable state in the vicinity of a second-order phase transition needs more careful analysis and will help clarify not only the particular nature of this transition, but it is possible to see some common features of such transitions.

\section{ORCID IDs}

망olymyr M. Kuklin http://orcid.org/0000-0002-0310-1582, (DEugen V. Poklonskiy https://orcid.org/0000-0001-5682-6694

\section{REFERENCES}

[1] J. Chapman and M.R.E. Proctor, J. Fluid Mech. 101, 759-765 (1980), https://doi.org/10.1017/S0022112080001917.

[2] V. Gertsberg, and G.E. Sivashinsky, Prog. Theor. Phys. 66, 1219-1229 (1981), https://doi.org/10.1143/PTP.66.1219.

[3] J.V. Swift and P.C. Hohenberg, Phys. Rev. A, 15, 319 (1977), https://doi.org/10.1103/PhysRevA.15.319.

[4] M.I. Rabinovich, A.L. Fabricant and L.S. Zimring, Soviet Physics-Uspekhi, 162(8), 1-42 (1992).

[5] E. Bodenschatz, J.R. de Bruyn, G. Ahlers and D. Connell, Preprint, (Santa Barbara, 1991).

[6] I.V. Gushchin, A.V. Kirichok and V.M. Kuklin, VANT series "Plasma Electronics and New Methods of Acceleration", 4, 252-254, (2015).

[7] I.V. Gushchin, A.V. Kirichok and V.M. Kuklin, Journal of Kharkiv National University, physical series "Nuclei, Particles, Fields", 1040(57), 4-27 (2013), https://periodicals.karazin.ua/eejp/article/view/13556.

\section{ФАЗОВЫЕ ПЕРЕХОДЫ В КОНВЕКЦИИ \\ И.В. Гущин, В.М. Куклин, Е.В. Поклонский \\ Харьковский национальный университет имени В. Н. Каразина, Харьков, Украина пл. Свободы 4, г. Харьков, Украина, 61022}

В работе представлены результаты изучения моделей описания конвективной неустойчивости вблизи ее порога тонких слоев жидкости и газа, ограниченных плохо проводящими стенками. Эти модели выделяют один пространственный масштаб взаимодействия, оставляя для эволюции системы возможность выбрать характер симметрии. Это связано с тем, что выбраны условия реализации режимов конвективной неустойчивости вблизи ее порога. Все пространственные возмущения одного пространственного масштаба, но разной ориентации взаимодействуют между собой. Оказалось, что наличие минимумов потенциала взаимодействия мод уравнений Проктора-Сивашинского, абсолютная величина векторов волновых чисел которых неизменна, и определяет выбор симметрии и соответственно характеристики пространственной структуры. В случае более реалистичной модели конвекции, описываемой уравнением Проктора-Сивашинского, удалось наблюдать процессы как структурно-фазового перехода первого рода, так и процесс фазового перехода второго рода и обнаружить вид функции состояния, которая отвечает за топологию образовавшихся конвективных структур: метастабильных валов и стабильных квадратных ячеек. В данной работе показано, что характер структурно-фазового перехода первого рода в жидкости при учете зависимости вязкости от температуры в модели Проктора-Сивашинского подобен случаю отсутствия такой зависимости. Время перехода оказывается тем же, несмотря на то, что формируется иная структура - шестигранные конвективные ячейки. Так же как в модели Свифта-Хоэнберга, возможен жесткий режим формирования шестигранных ячеек в газовой среде лишь для достаточно заметной зависимости ее вязкости от температуры. Времена фазовых переходов обратно пропорциональны разности значений этой функции для двух последовательных состояний. Подобное описание фазовых переходов не использовало феноменологические подходы и различные спекулятивные соображения, что позволяет более пристально рассмотреть характер переходных процессов.

КЛЮЧЕВЫЕ СЛОВА: фазовые переходы первого рода, фазовые переходы второго рода, конвективные структуры, функция состояния, модели Свифта -Хоэнберга и Проктора-Сивашинского.

\section{ФАЗОВІ ПЕРЕХОДИ В КОНВЕКЦІЇ \\ І.В. Гущин, В.М. Куклін, Е.В. Поклонский \\ Харківський національний університет імені В. Н. Каразіна, Харків, Украйна \\ пл. Свободи 4, м Харків, Україна, 61022}

У роботі представлено результати вивчення моделей опису конвективної нестійкості поблизу ії порога тонких шарів рідини і газу, обмежених стінками, що слабко проводять тепло. Ці моделі виділяють один просторовий масштаб взаємодії, залишаючи для еволюції системи можливість вибрати характер симетрії. Це пов'язано з тим, що обрані умови реалізації режимів конвективної нестійкості поблизу ії порогу. Всі просторові збурення одного просторового масштабу, але різної орієнтації взаємодіють між собою. Виявилося, що наявність мінімумів потенціалу взаємодії мод рівнянь ПроктораСівашінского, абсолютна величина векторів хвильових чисел яких незмінна, і визначає вибір симетрії та характеристик 
просторової структури. У випадку більш реалістичної моделі конвекції, описуваної рівнянням Проктора-Сівашінского, вдалося спостерігати процеси як структрно-фазового переходу першого роду, так і процес структурно-фазового переходу другого роду і виявити вид функції стану, яка відповідає за топологію конвективних структур: метастабільних валів і стабільних квадратних структур. У даній роботі показано, що характер структурно-фазового переходу першого роду в рідини при урахуванні залежності в'язкості від температури в моделі Проктора-Сівашінского подібний випадку при відсутності такої залежності. Час переходу виявляється тим же, не дивлячись на те, що формується інша структура шестигранні конвективні структури. Так само як в моделі Свіфта-Хоенберга, можливий жорсткий режим формування шестигранних структур в газовому середовищі лише для досить помітною залежності їі в'язкості від температури. Часи фазових переходів обернено пропорційні різниці значень цієї функції для двох послідовних станів. Подібний опис фазових переходів не використав феноменологічні підходи і різні спекулятивні міркування, що дозволяє більш пильно розглянути характер перехідних процесів.

КЛЮЧОВІ СЛОВА: фазові переходи першого роду, фазові переходи другого роду, конвективні структури, функція стану, моделі Свіфта -Хоенберга і Проктора-Сівашінского. 